\title{
Changes in the phytoplankton community and microbial food web of Blanes Bay (Catalan Sea, NW Mediterranean) under prolonged grazing pressure by doliolids (Tunicata), cladocerans or copepods (Crustacea)
}

\author{
Alexis Katechakis ${ }^{1, *}$, Herwig Stibor ${ }^{1}$, Ulrich Sommer ${ }^{2}$, Thomas Hansen ${ }^{2}$ \\ ${ }^{1}$ Zoologisches Institut, Ludwig-Maximilians-Universität, Abteilung Aquatische Ökologie, Karlstraße 23-25, \\ 80333 München, Germany \\ ${ }^{2}$ Institut für Meereskunde, Christian-Albrechts-Universität, Abteilung Experimentelle Ökologie, Düsternbrooker Weg 20, \\ 24105 Kiel, Germany
}

\begin{abstract}
We report how different zooplankton groups (doliolids, cladocerans and copepods) are able to influence the coastal pelagic food web, including the microbial food web, in waters of the NW Mediterranean. We studied the effect of grazing and of grazing-induced nutrient recycling mediated by different types of zooplankton grazing on a natural phytoplankton community. Experiments were conducted in semicontinuous 2-stage chemostats. The 1st stage vessels contained seawater from Blanes Bay, Spain (NW Mediterranean) including its natural phytoplankton community; the 2nd stage vessels contained the same seawater and copepods, cladocerans or doliolids. At daily intervals we transferred part of the medium from the 2nd to the 1st stage flasks, which contained ungrazed algae and excreted nutrients. In this way, the zooplankton could influence phytoplankton dynamics both by selective grazing and by differential excretion of limiting nutrients. In the 2nd stage flasks grazing changed the algal community composition. Doliolids and cladocerans promoted the growth of large algae and copepods shifted the size spectrum towards small sizes. This effect was transferred to the 1st stage flasks. Doliolids, cladocerans and copepods also affected the microbial food web in different ways. Size-selective grazing led to differences in the nanoplankton concentrations. These in turn affected bacterial concentrations in a trophic cascade. The potential to modify a given algal population increased with increasing selectivity of the grazer.
\end{abstract}

KEY WORDS: Doliolids $\cdot$ Cladocerans $\cdot$ Copepods $\cdot$ Grazing $\cdot$ Marine pelagic food web $\cdot$ Microbial food web - Trophic cascade

Resale or republication not permitted without written consent of the publisher

\section{INTRODUCTION}

The grazing behaviour of herbivorous mesozooplankton is one of the critical factors structuring pelagic food webs. Herbivores distribute the organic matter synthetized by autotrophs to higher trophic lev-

*E-mail: katechakis@zi.biologie.uni-muenchen.de els. In spite of some recent controversy (Miralto et al. 1999, Tang \& Dam 2001), the energy flow from diatoms via crustaceans to fishes is considered particularly efficient (Cushing 1975, Officer \& Ryther 1980, Iverson 1990, Sommer et al. 2002). In contrast, gelatinous zooplankton are considered a poor food base for commercial fish stocks (Verity \& Smetacek 1996), due to their high volume to plasma ratio and their low protein content (Cushing 1975). 
There are many studies concerning grazing by marine copepods and their influence on the marine pelagic food web structure (e.g. Kiørboe 1998). Gelatinous mesozooplankton and cladocerans are poorly investigated in this context, although seasonally they may dominate zooplankton communities at times (e.g. Alldredge \& Madin 1982, Deibel 1982a,b, 1998, Crocker et al. 1991, Paffenhöfer et al. 1991, Andreu \& Duarte 1996).

Besides exerting direct grazing pressure, zooplankton may also influence the phytoplankton community indirectly (Gismervik et al. 1996 review, Andersen 1997). Whilst feeding on algae, herbivores release nutrients through excretion and sloppy feeding. The regeneration of dissolved nutrients may influence the gross growth rate of the algal community. A changing nutrient-stoichiometry can alter its composition (e.g. Officer \& Ryther 1980, Tilman 1982, Sommer 1983, 1994a, 1996, 1998a, Tilman et al. 1986, Hessen \& Andersen 1992, Escaravage et al. 1996, Schöllhorn \& Granéli 1996). This might feed back on the competition within the herbivorous zooplankton and affect the energy transfer in the pelagic food web (e.g. Sommer 1998b).

To study the effects of grazing and grazing-induced nutrient regeneration, we conducted experiments with mesozooplankton from Blanes Bay (Catalan Sea, NW Mediterranean) feeding on a natural phytoplankton assemblage. Three zooplankton groups dominated in Blanes Bay in summer: copepods, cladocerans and doliolids. Short-term grazing experiments (several hours) with these zooplankton groups showed that they differ in their size preference for algae; therefore, they can influence the competition between differentsized algal groups (Katechakis 1999). This makes them well-suited for longer experiments (several weeks) to investigate how copepods, cladocerans and doliolids influence the algal community over several phytoplankton generations.

\section{MATERIALS AND METHODS}

Experimental setup. Experiments were performed in semicontinuous 2-stage chemostats, consisting of $600 \mathrm{ml}$ tissue culture flasks. The 1st stage flasks were filled with the natural phytoplankton community occurring in summer in Blanes Bay (Catalan Sea, NW Mediterranean, $42^{\circ} 18^{\prime} 26^{\prime \prime} \mathrm{N}, 3^{\circ} 18^{\prime} 11^{\prime \prime} \mathrm{E}$ ); water was filtered through a plankton net with a mesh size of $100 \mu \mathrm{m}$ to exclude mesozooplankton. To the 2 nd stage flasks (reaction chambers) we added 20 copepods (Acartia sp.), 20 cladocerans (Penilia avirostris) or 15 doliolids (solitary gonozooids of Doliolum denticulatum), at higher densities than those in summer in
Blanes Bay (natural densities: 500 to 780 copepods $\mathrm{m}^{-3}$, 750 to 1250 cladocerans $\mathrm{m}^{-3}, 90$ doliolids $\mathrm{m}^{-3}$ : Andreu \& Duarte 1996). We were careful to incubate similar biovolumes of grazers in the various flasks. We estimated biovolumes from size measurements. All treatments were replicated 3 times, including controls without grazers. The replicates were placed randomly in a water bath at a temperature between 21 and $23^{\circ} \mathrm{C}$. The in situ surface temperature in Blanes Bay was 25 to $26^{\circ} \mathrm{C}$ (measured with a WTW LF 20 temperature sensor). The 1st stage flasks were ventilated with air pumps and illuminated with 6 fluorescent tubes $(3 \times$ Osram light code 77, 3× Osram light code 21-840, 36 W each). The reaction chambers remained dark and were not ventilated-preliminary experiments had shown that bubbling affected especially cladocerans and doliolids adversely. We took $150 \mathrm{ml}$ from the 1 st and 2 nd stage flasks daily (dilution rate, $D=0.25 \mathrm{~d}^{-1}$ ). The $150 \mathrm{ml}$ from the 1st stage flasks were transferred to the 2nd stage flasks. Of the $150 \mathrm{ml}$ taken from the 2nd stage flasks, $75 \mathrm{ml}$ were returned to the 1st stage flasks, together with uneaten algae and recycled nutrients but without transferring mesozooplankton grazers; $75 \mathrm{ml}$ were used for sampling or discarded. Sampling was done 4 times during the experiment: at the beginning, after $6 \mathrm{~d}$, after $12 \mathrm{~d}$ and at the end. Sampling of 1st stage flasks after $6 \mathrm{~d}$ and after $12 \mathrm{~d}$ resulted in dilution rates higher than $0.25 \mathrm{~d}^{-1}$; however we estimated this to be no problem taking into account the duration of the experiment. Sampling at the beginning and at the end did not influence the dilution rate. The $75 \mathrm{ml}$ deficits in 1st stage flasks were made up with fresh medium (Fig. 1) consisting of sterile-filtered seawater $(0.2 \mu \mathrm{m}$ cellulose-acetate filters) enriched with nutrients $\left(\mathrm{N}, 21 \mu \mathrm{M}: 50 \% \mathrm{NaNO}_{3}\right.$ and $50 \% \mathrm{NH}_{4} \mathrm{Cl}_{\text {; }}$ $\mathrm{P}, 1 \mu \mathrm{M}: \mathrm{Na}_{2} \mathrm{HPO}_{4} \cdot 2 \mathrm{H}_{2} \mathrm{O} ; \mathrm{Si}, 7 \mu \mathrm{M}: \mathrm{Na}_{2} \mathrm{O}_{3} \mathrm{Si} \cdot 5 \mathrm{H}_{2} \mathrm{O}$ ), which is similar to the in situ supply from natural terrestial and human sources during summer in Blanes Bay (Y. Olsen unpubl. data). During the experimental period of $17 \mathrm{~d}$ we visually controlled whether grazers were intact several times a day by observing their swimming behaviour in the flasks. Injured individuals were replaced if necessary. Animals were not reproducing during the experiment.

Sample preparation and analysis. The recirculating design permitted the zooplankton to influence the phytoplankton community in 2 ways-directly through grazing impact and indirectly through excretion of limiting nutrients. To determine grazer-induced changes in abundance, species composition, biovolume and the biomass of the nano- and microplankton, we preserved samples with Lugol's iodine $\left(5 \mathrm{~g} \mathrm{I}_{2}+10 \mathrm{~g}\right.$ $\mathrm{KI}$ ad $100 \mathrm{ml}$ aq. dest.). We counted the samples using an inverse microscope (Leica DMIL; Utermöhl 1958). If present, we counted at least 400 cells of each species to 


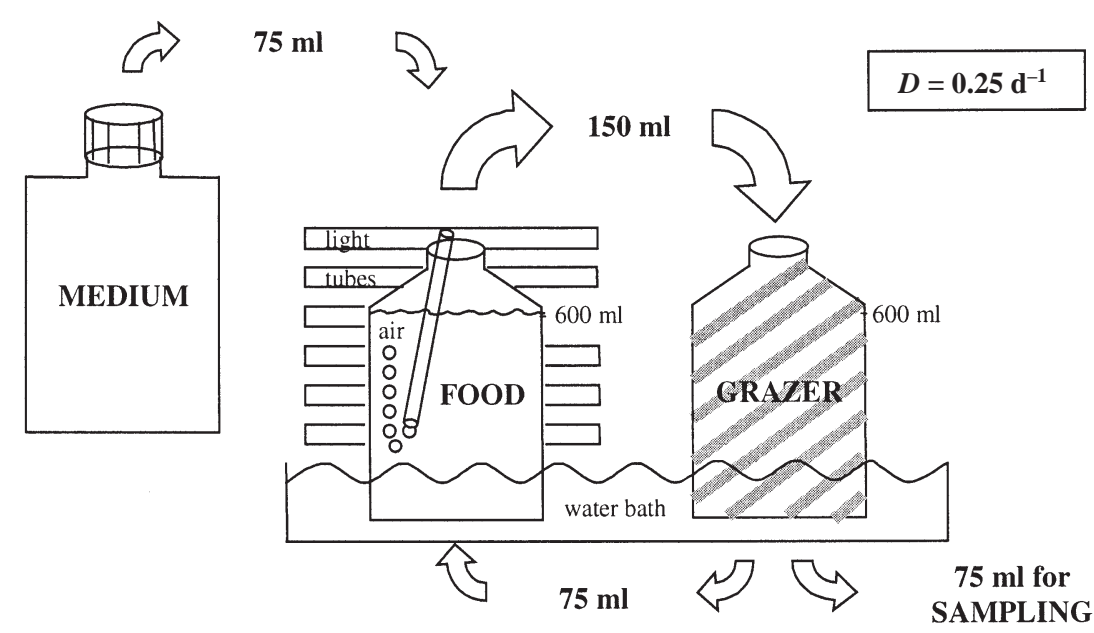

Fig. 1. Scheme illustrating the experimental setup (for details see 'Materials and methods'). $D$ : dilution rate

achieve an error of $<10 \%$ (Lund et al. 1958). Biovolumes were calculated using the equations of Hillebrand et al. (1999); for this purpose we measured the linear dimensions of 20 specimens of each species. Carbon contents were estimated after Strickland \& Parsons (1972).

Booth et al. (1982) and Reid (1983) criticized the Utermöhl method, suggesting it underestimates picoand small nanoplankton abundances drastically. Therefore we determined the abundances of bacteria, naked flagellates $<5 \mu \mathrm{m}$ and dinoflagellates $<10 \mu \mathrm{m}$ by staining with DAPI (4,6-diamidino-2-phenylindol) (Porter \& Feig 1980). We fixed samples in formalin (final concentration: $2 \%$ ) and stained them with a final concentration of $1.76 \mu \mathrm{g}$ DAPI $\mathrm{ml}^{-1}$ for bacteria and $2.45 \mu \mathrm{g}$ DAPI $\mathrm{ml}^{-1}$ for flagellates. After $10 \mathrm{~min}$, the samples were filtered onto black $0.2 \mu \mathrm{m}$ polycarbonate filters (Millipore) and $0.8 \mu \mathrm{m}$ filters (Nuclepore), respectively. Filters were rinsed with $5 \mathrm{ml}$ washing solution (sterile filtered tap water, 2\% formaldehyde). Counts were done using an epifluorescence microscope (Leitz DMRB) equipped with a blue light and an UV-light filter set. For bacteria, at least 400 cells of each morphotype were enumerated if present. Bacteria attached to particles were counted as 'particle-bound bacteria cells', independent of particle size and abundance measurements. Naked flagellates and dinoflagellates were divided into 3 size classes: 2.5 to $5 \mu \mathrm{m},>5$ to $7.5 \mu \mathrm{m}$ and $>7.5$ to $10 \mu \mathrm{m}$, of which at least 400, 200 or 100 cells, respectively, were counted. To calculate biovolumes we measured the linear dimensions of 50 specimen of each morphotype (Fuhrmann \& Azam 1980, Bjørnsen 1986). Flagellate biovolumes were calculated on the base of the respective interval means of every size class $(3.75,6.3$, $8.8 \mu \mathrm{m})$. The carbon content of bacteria was calculated by multiplying cell numbers with $23.3 \mathrm{fg} \mathrm{C}_{\mathrm{Cell}}^{-1}$
(Simon \& Azam 1989). Flagellate biomass was estimated with $0.22 \mathrm{pgC} \mu^{-3}$ according to Bøsheim \&

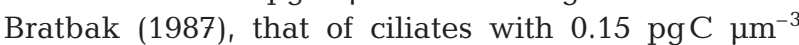
(DeBiase et al. 1990). Moreover, under blue light stimulation, the differentiation of autotrophic cells (chlorophyll a: red autofluorescence) and heterotrophic cells (green coloration) was possible, as well as the detection of cyanobacteria (chl a + accessory phycobilines: yellow-orange coloration). DAPI-countings were done for 1st stage flasks.

Dissolved inorganic nutrients were analyzed with a continuous flow analyser using the methods of Grasshoff et al. (1983) for silicate, nitrate, ammonium and phosphate. For the determination of particulate carbon and nitrogen we filtered samples onto precombusted Whatman GF/C filters and measured them with a Fisons CN-analyser (NA 1500N).

Similarities between the resulting communities at the end of the experiment in the 1st stage flasks were expressed as Euclidean distances (Eq. 1), based on the following groups: cyanobacteria, naked flagellates, ciliates, dinoflagellates, diatoms and amoeba.

$$
\Delta_{j k}=\sqrt{\sum_{i=1}^{n}\left(X_{i j}-X_{i k}\right)^{2}}
$$

where $\Delta_{j k}=$ Euclidean distance between Chemostats $j$ and $k_{i} X_{i j}=$ proportion of Group $i$ of total biovolume in Chemostat $j$ ( $X_{i k}$ analog) and $n=$ total number of groups. $\Delta_{j k}$ increases with increasing $n$. To compensate for this we calculated the average distance $d_{j k}$ (Eq. 2):

$$
d_{j k}=\sqrt{\frac{\Delta_{j k}^{2}}{n}}
$$

Both $\Delta_{j k}$ and $d_{j k}$ vary from 0 to $+\infty$; the larger the distance, the less similar are the 2 communities.

Data analysis. For statistical analysis, SigmaStat 2.0 and SPSS 10.0.5 software was used. 

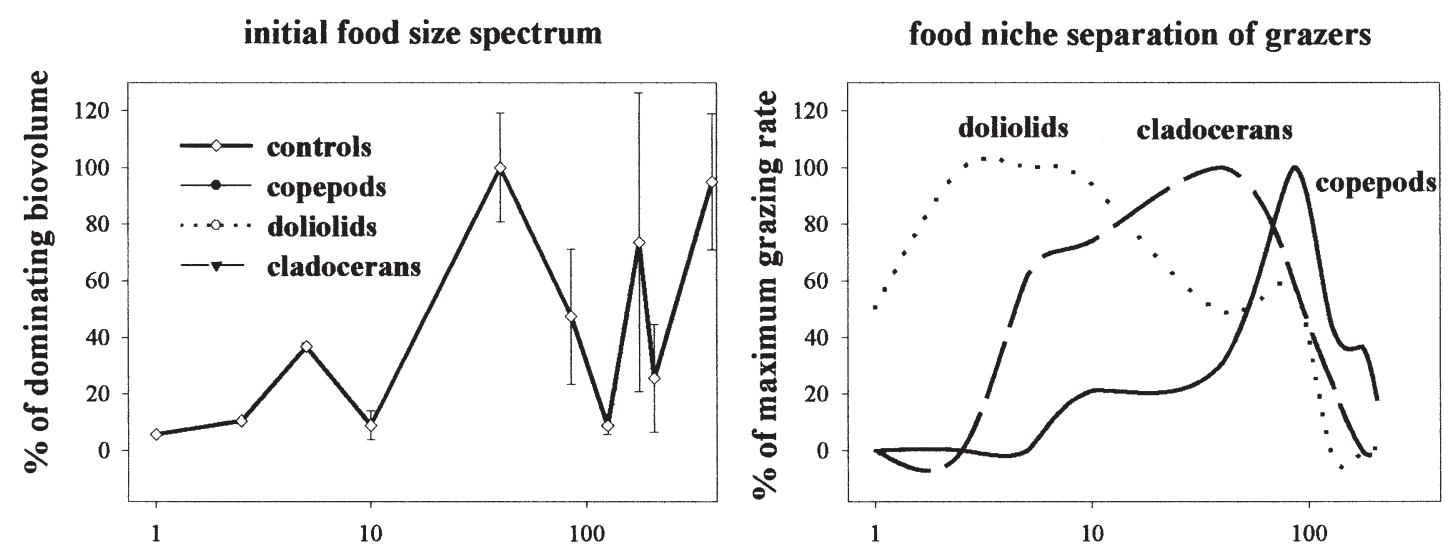

\section{food size spectra in $1^{\text {st }}$ stage flasks}
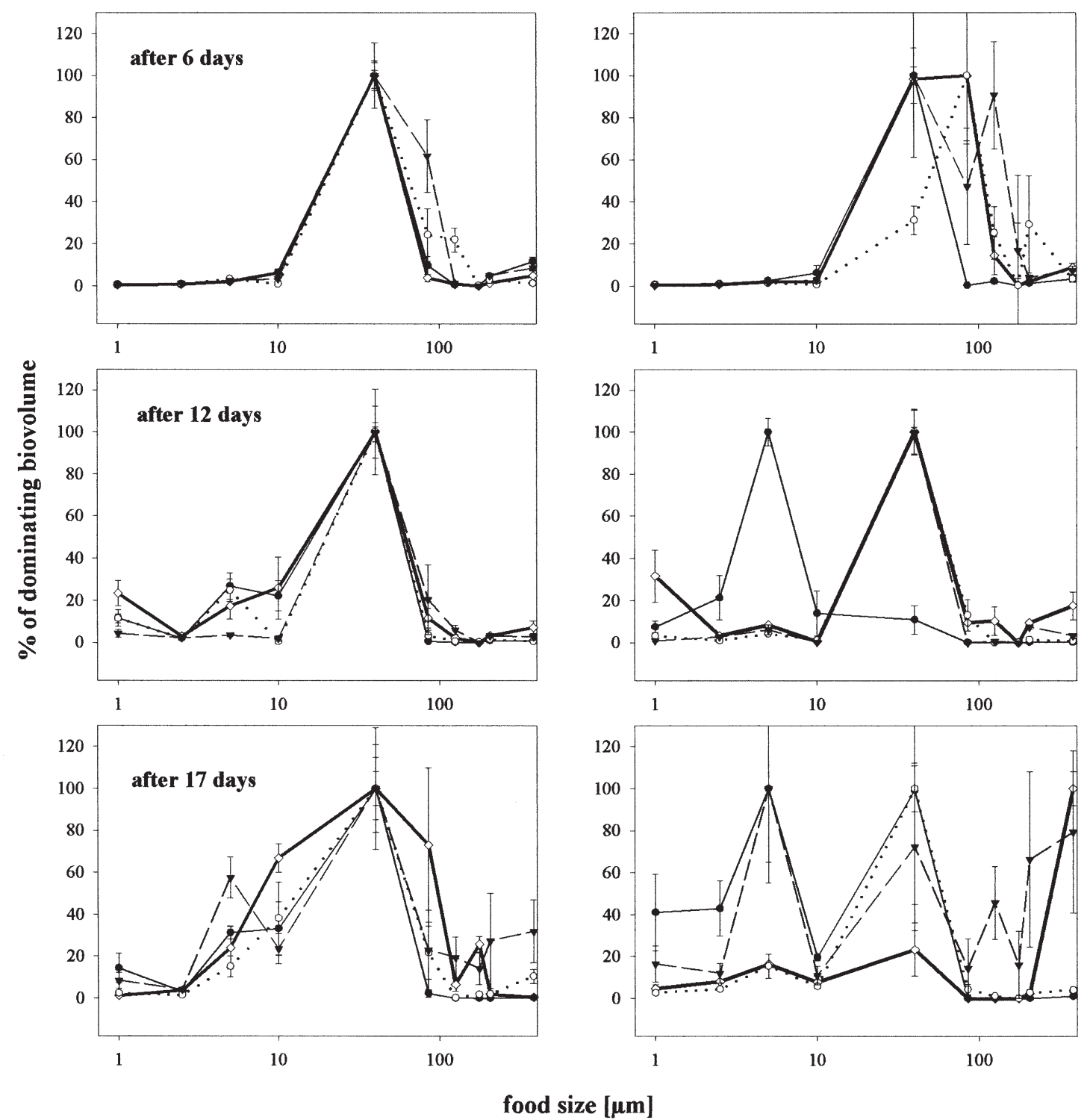

Fig. 2. Changes in the size composition of the summer plankton community of Blanes Bay (NW Mediterranean) under prolonged grazing pressure by doliolids, cladocerans or copepods in semicontinuous 2-stage chemostats (1st stage: food without grazer, 2nd stage: reaction chamber). Top left: initial seawater; top right: grazing spectra of doliolids, cladocerans and copepods as evaluated in grazing experiments (Katechakis 1999). Data points are means of triplicates; error bars represent \pm SE of the means. Note logarithmic scale of particle-size axes 


\section{RESULTS}

\section{Changes in composition of food guilds}

\section{Size composition}

Fig. 2 shows how the size composition within the food changed under the persisting grazing pressure of copepods, cladocerans or doliolids. We subdivided the plankton community into 9 size classes with mean intervals of $1,2.5,5,10,40,85,125,175$ and $205 \mu \mathrm{m}$. Colonial species were assigned to classes according to the biggest linear dimension of colonies. For the following comparisons of size classes we set the biovolume of the most abundant size class at $100 \%$ and refer to it as the 'dominating biovolume'.

\section{Initial seawater}

The size spectrum of food types initially presented to grazers was dominated by organisms between 15 and $70 \mu \mathrm{m}$ (for comparitive purposes we set the biovolume at $100 \pm 19.2 \%$ SE of the means: Fig. 2). Microplankton from 150 to $200 \mu \mathrm{m}$ and $>210 \mu \mathrm{m}$ made up $73.7 \pm 52.7 \%$ of the dominating biovolume and $95.0 \pm 24.0 \%$ of the dominating biovolume, respectively. Among small size classes only individuals around $5 \mu \mathrm{m}$ were important (36.6 $\pm 1.4 \%)$.

\section{Second stage flasks (reaction chambers)}

In 2nd stage flasks copepods, cladocerans and doliolids caused size compositions according to their respective grazing spectra, as evaluated in grazing experiments (Katechakis 1999 and present Fig. 2: right), with the following exceptions: After $17 \mathrm{~d}$, chemostats with cladocerans showed high biovolumes of intermediate food sizes between 15 and $70 \mu \mathrm{m}$ $(72.4 \pm 40.0 \%$ of the dominating biovolume) compared to controls, and in chemostats with doliolids large food items $>100 \mu \mathrm{m}$ were efficiently reduced. Controls were dominated by intermediate food sizes after $6 \mathrm{~d}$ and 12 d. Lastly, organisms $>210 \mu \mathrm{m}$ prevailed in control flasks. Differences among treatments were tested for significance using 2-way ANOVAs with the factor grazer type as a fixed factor and food size as a random factor. For percentages of dominating biovolume original data were arcsine-transformed. The interaction between different grazers and phytoplankton size composition was significant ( $\left.p \leq 0.001, F_{9,24}=4.904\right)$.

\section{First stage flasks}

Shifts in food size composition were transferred to 1st stage flasks ( $p \leq 0.05, F_{9,24}=2.443$ ) through recurrent inoculation with small amounts of material from the 2nd stage flasks.
Taxonomic composition

Initial seawater: The initial community was dominated by diatoms, ciliates and organisms $<5 \mu \mathrm{m}$. Dinophyceae and naked flagellates were of little importance. Abundances of amoebae lay below the detection limit initially but became detectable later. The most important species were Rhizosolenia fragilissima and Skeletonema costatum. Together they accounted for more than $55 \%$ of the total food biovolume (for details see Table 2). The whole taxonomic spectrum is listed in Table 1.

Second stage flasks (reaction chambers): By Day 6, the taxonomical composition of the various chemostats differed little. Diatoms extended their dominance in all treatments. Compared to the initial community, picoand nanoplankton showed substantial decreases in all flasks. Ciliates decreased in the copepod and doliolid treatments (Tables $2 \& 3$ ). After $12 \mathrm{~d}$ the communities had changed radically. In all flasks with grazers, nonsiliceous species had become predominant: naked flagellates in chemostats with copepods, dinoflagellates (mainly Peridinium sp. accompanied by Prorocentrum micans) in those with doliolids or cladocerans. After $17 \mathrm{~d}$, communities with different treatments differed greatly from each other. By Day 12 of the experiment, the prevailing naked flagellates had declined in the copepod chambers, while pico- and nanoplankton $<5 \mu \mathrm{m}$ and Peridinium sp. increased. Peridinium sp. was also the outstanding taxon under the influence of doliolids. In both chemostats with cladocerans and controls, diatoms gained importance, whereas dinophyceaes declined slightly. For details see Table 3.

First stage flasks: Here the central characteristic was the rise in dinophyceaens at the expense of diatoms. The change was expressed by the shift from Rhizosolenia spp. and Skeletonema costatum to Peridinium sp. and Prorocentrum micans as the most important species. Except for cladoceran treatments this was valid for all chemostats, although most evident in copepod systems.

Similarity of communities: The most dissimilar communities resulted from the influence of selective grazers (copepods) on the one hand and unselective filterfeeders (cladocerans or doliolids) on the other hand (Table 4). The latter were more similar to each other. The most similar communities were chemostats with doliolids and those serving as controls.

\section{Changes in composition of microbial food web (1st stage flasks)}

Bacteria and cyanobacteria

Solitary bacteria abundances: Solitary bacteria (dia-

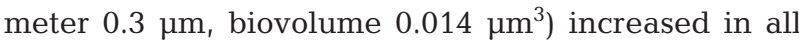


Table 1. Taxonomic list of all plankton food in chemostat experiments. Biovolumes were calculated using the equations of Hillebrand et al. (1999). Carbon contents were estimated after Strickland \& Parsons (1972) for phytoplankton, after Bøsheim \& Bratbak (1987) for flagellates and after DeBiase et al. (1990) for ciliates. ANF: autotrophic nanoflagellates; HNF: heterotrophic nanoflagellates

\begin{tabular}{|c|c|c|c|c|}
\hline Taxon & $\begin{array}{l}\text { Geometrical } \\
\text { shape }\end{array}$ & $\begin{array}{l}\text { Cell dimension }(\mu \mathrm{m}) \\
\text { biggest extension }\end{array}$ & $\begin{array}{l}\text { Biovolume } \\
\left(\mu \mathrm{m}^{3} \text { cell }^{-1}\right)\end{array}$ & $\begin{array}{c}\text { Biomass } \\
\left(\mathrm{pgC} \mathrm{cell}^{-1}\right)\end{array}$ \\
\hline \multicolumn{5}{|l|}{ Picoplankton } \\
\hline $1 \mu \mathrm{m}$ & Sphere & 1 & 0.52 & 0.07 \\
\hline \multicolumn{5}{|l|}{ Nanoplankton } \\
\hline $2.5 \mu \mathrm{m}$ & Sphere & 2.5 & 8.2 & 1.2 \\
\hline $5 \mu \mathrm{m}$ & Sphere & 5 & 65 & 9.2 \\
\hline \multicolumn{5}{|l|}{ Cyanobacteria } \\
\hline Coccal & Sphere & 0.5 & 0.07 & 0.01 \\
\hline Filamentous & Cylinder & $7.0-140$ & $0.88-17.6$ & $1.4-28$ \\
\hline \multicolumn{5}{|l|}{ Bacillariophyceae } \\
\hline \multicolumn{5}{|l|}{ Centrales } \\
\hline Biddulphia sp. & Elliptic prism & 15 & 442 & 39 \\
\hline Coscinodiscus sp. & Cylinder & $12.5-40$ & $920-12566$ & $81-1100$ \\
\hline Chaetoceros sp. A & Elliptic prism & 5 & 79 & 6.9 \\
\hline Chaetoceros sp. B & Elliptic prism & 20 & 707 & 62 \\
\hline Leptocylindrus sp. & Cylinder & 45 & 884 & 77 \\
\hline Rhizosolenia deliculata & Cylinder & 28 & 2160 & 189 \\
\hline Rhizosolenia fragilissima & Cylinder & $18-75$ & $344-5890$ & $30-515$ \\
\hline Rhizosolenia stolterfothii & Cylinder & $38-200$ & $1657-62832$ & $145-5498$ \\
\hline Rhizosolenia sp. A & Cylinder & 70 & 3093 & 271 \\
\hline Rhizosolenia sp. B & Cylinder & $100-500$ & $1964-9817$ & $172-859$ \\
\hline Skeletonema costatum & Cylinder +2 halfspheres & $7.5-25$ & $94-1104$ & $8-97$ \\
\hline Thalassiosira sp. & Cylinder & 20 & 3534 & 309 \\
\hline \multicolumn{5}{|l|}{ Pennales } \\
\hline Licmophora sp. & Gomphonemoid & 75 & 10000 & 875 \\
\hline Navicula sp. & Elliptic prism & 15 & 147 & 13 \\
\hline Nitzschia closterium & Prism on parallelogram & 30 & 94 & 8.2 \\
\hline Nitzschia longissima & Prism on parallelogram & 75 & 125 & 11 \\
\hline Nitzschia sp. A & Prism on parallelogram & $17.5-30$ & $47-156$ & $4.1-14$ \\
\hline Nitzschia sp. B & Prism on parallelogram & 70 & 125 & 11 \\
\hline Thalassionema nitzschioides & Box & 40 & 785 & 69 \\
\hline \multicolumn{5}{|l|}{ Dinophyceae } \\
\hline \multicolumn{5}{|l|}{ Dinophysiales } \\
\hline Dinophysis sp. & Ellipsoid & 50 & 10472 & 1466 \\
\hline \multicolumn{5}{|l|}{ Peridiniales } \\
\hline Ceratium tripos & 3 cones + cylinder & 50 & 25000 & 3500 \\
\hline Gymnodinium sp. & Ellipsoid & 10 & 654 & 92 \\
\hline Peridinium sp. & Ellipsoid & $15-30$ & $1767-9425$ & $247-1319$ \\
\hline \multicolumn{5}{|l|}{ Prorocentrales } \\
\hline Prorocentrum micans & Cone + halfsphere & $30-50$ & $2209-6283$ & $309-880$ \\
\hline \multicolumn{5}{|l|}{ Prymnesiophyceae } \\
\hline Coccolithus sp. & Sphere & 7.5 & 221 & 31 \\
\hline Phaeocystis pouchetii & Sphere & 7.5 & 221 & 73 \\
\hline \multicolumn{5}{|l|}{ Other flagellates } \\
\hline$A N F \mathrm{spp}$ & Sphere & $2.5-10$ & $8.2-523$ & $1.8-73$ \\
\hline$H N F$ spp. & Sphere & $2.5-10$ & $8.2-523$ & $1.8-73$ \\
\hline \multicolumn{5}{|l|}{ Ciliata } \\
\hline Ciliate sp. & Ellipsoid & 25 & 29452 & 4123 \\
\hline \multicolumn{5}{|l|}{ Amoeba } \\
\hline Amoeba sp. & Irregular & $7.5-15$ & $331-2651$ & $46-371$ \\
\hline
\end{tabular}


Table 2. Taxonomic composition (\% of total food guild biovolume and $\mathrm{SE}$ of means in chemostats) of the food presented to grazers in the initial seawater at the beginning of the experiment

\begin{tabular}{|lc|}
\hline Functional group & $\%$ \\
\hline Pico/nanoplankton $<5 \mu \mathrm{m}$ & $15.26 \pm 0.87$ \\
Diatoms & \\
Total & $57.21 \pm 6.70$ \\
Skeletonema costatum & $20.66 \pm 0.38$ \\
Rhizosolenia fragilissima & $35.21 \pm 6.00$ \\
Dinophyceae & $2.52 \pm 1.39$ \\
Naked flagellates & $2.51 \pm 2.54$ \\
Ciliates & $22.49 \pm 5.25$ \\
Amoeba & 0 \\
\hline
\end{tabular}

treatments. At the end of the experiment, controls showed lower values than chemostats with grazers. Biovolumes were highest in cladoceran-influenced systems followed by those systems affected by doliolids or copepods (Fig. 3). The cell numbers in the 1st stage chemostats differed significantly from each other (1-way ANOVA, $\mathrm{p} \leq 0.001, F_{4,14}=16.64$ ). Post hoc Tukey-test analyses showed a significant difference between the cladoceran and all the other treatments.

Particle-bound bacteria: We could not find any of these in natural seawater; 17 d later, in the chambers with doliolids most bacteria were attached to particles $\left(2.81 \times 10^{5}\right.$ cells $\left.\mathrm{ml}^{-1}\right)$, while the remaining chambers had densities of 55200 cells $\mathrm{ml}^{-1}$ (cladocerans), 51886 cells ml ${ }^{-1}$ (controls), and 8529 cells ml$^{-1}$ (cope- pods). Differences among treatments were significant (1-way ANOVA, $\left.\mathrm{p} \leq 0.001, F_{4,14}=15.132\right)$. Post hoc Tukey-test analyses showed that the doliolid treatments formed a separate group.

Coccal cyanobacteria abundances: Coccal cyanobacteria (diameter $0.5 \mu \mathrm{m}$, biovolume $0.065 \mu^{3}$ ) were below the detection limit in the initial samples and did not occur in chemostats with doliolids. They reached highest abundances $\left(5.66 \times 10^{5}\right.$ cells ml $\left.{ }^{-1}\right)$ in controls, followed by the treatments with cladocerans and with copepods, in that order (Fig. 3). Chemostats differed significantly from each other (1-way ANOVA, $\mathrm{p} \leq 0.05$, $F_{4,14}=4.109$ ). Post hoc Tukey-test analyses showed that systems with doliolids and the initial sample represented separate groups.

Filamentous cyanobacteria: These could not be found at the beginning of the experiment but occurred in all treatments at the end. Filamentous cyanobacteria had a diameter of $0.4 \mu \mathrm{m}$ and covered lengths from 7 to $140 \mu \mathrm{m}$ in all chemostats. The mean sizes of filamentous cyanobacteria were larger in treatments with doliolids as grazers (length $38.2 \pm$ $1.6 \mu \mathrm{m}$ SE, biovolume $4.8 \pm 0.2 \mu \mathrm{m}^{3} \mathrm{SE}$ ) than in other treatments (copepods: $29.1 \pm 1.8 \mu \mathrm{m}$ and $3.7 \pm$ $0.2 \mu^{3}$, cladocerans: $25.9 \pm 1.1 \mu \mathrm{m}$ and $3.3 \pm 0.1 \mu^{3}$ ) and in controls $\left(29.1 \pm 0.6 \mu \mathrm{m}\right.$ and $\left.3.7 \pm 0.1 \mu^{3}\right)$. Doliolid chambers also contained the most filamen-

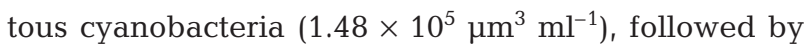
those with cladocerans or copepods and controls. Differences between treatments were significant (1-way ANOVA, $\left.\mathrm{p} \leq 0.05, F_{(4 ; 14)}=3.495\right)$. Post hoc Tukey-test analyses showed that doliolid treatments formed a separate group.
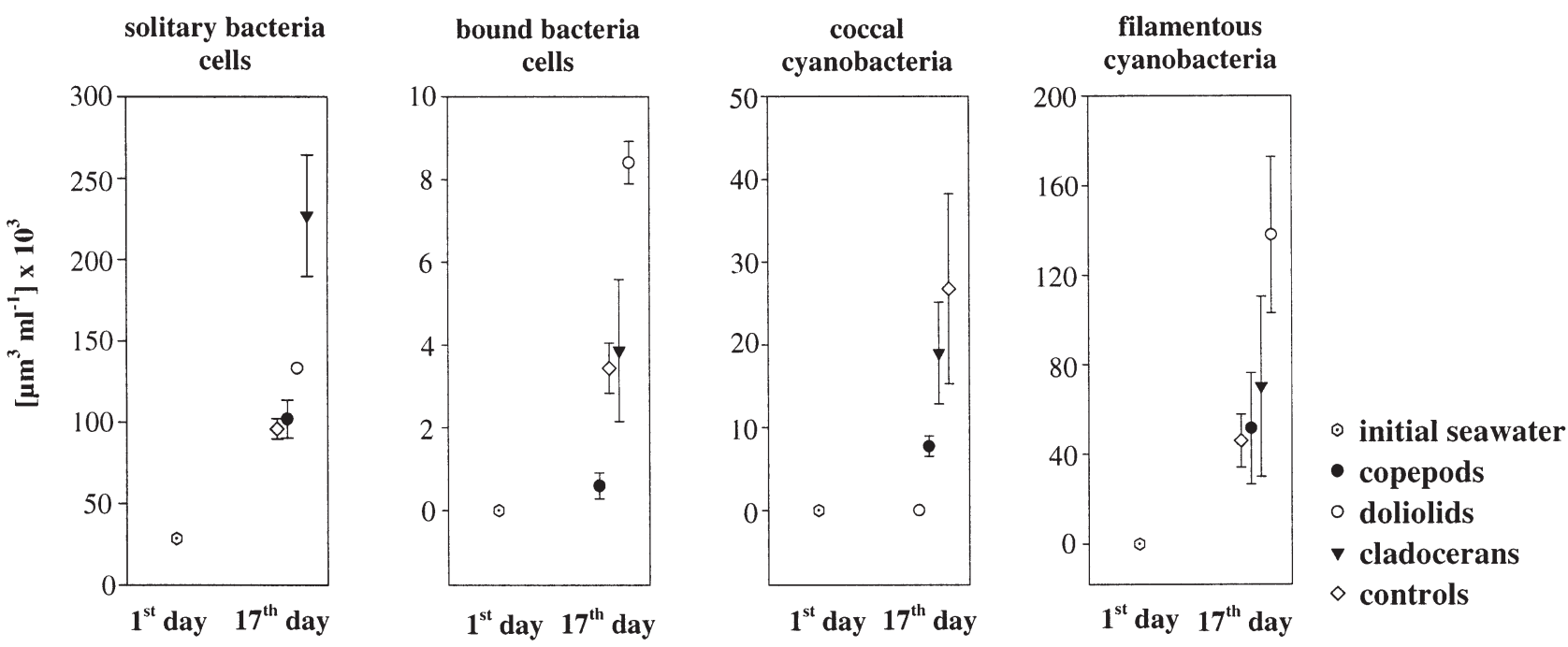

Fig. 3. Changes in the composition of the bacterial community of Blanes Bay (NW Mediterranean) under prolonged grazing pressure by doliolids, cladocerans or copepods (1st stage flasks). Data points are means of triplicates; error bars represent $\pm \mathrm{SE}$ 
Flagellates

We found a significant negative correlation between bacterial abundance (bacteria + coccal cyanobacteria) and the appearance of heterotrophic nanoflagellates (HNF) from 5.1 to $10 \mu \mathrm{m}$ size (Fig. 4). At the end of the experiment, chemostats with cladocerans as grazers showed the lowest HNF biovolumes $\left(3.68 \times 10^{5} \mu^{3}\right.$

Table 3. Changes in taxonomic composition (\% of total food guild biovolume and SE of the means in chemostats) of the summer plankton community in Blanes Bay (NW Mediterranean) under prolonged grazing pressure by doliolids, cladocerans or copepods in semicontinuous 2-stage chemostats (1st stage: food without grazers, 2nd stage: reaction chamber)

\begin{tabular}{|c|c|c|c|c|c|c|}
\hline \multirow{2}{*}{ Functional group } & \multicolumn{3}{|c|}{ 1st stage after } & \multicolumn{3}{|c|}{ 2nd stage after } \\
\hline & $6 \mathrm{~d}$ & $12 \mathrm{~d}$ & $17 \mathrm{~d}$ & $6 \mathrm{~d}$ & $12 \mathrm{~d}$ & $17 \mathrm{~d}$ \\
\hline \multicolumn{7}{|l|}{ Copepods } \\
\hline Pico/nanoplankton $<5 \mu \mathrm{m}$ & $2.19 \pm 0.27$ & $9.23 \pm 1.59$ & $5.60 \pm 1.20$ & $3.55 \pm 0.94$ & $16.91 \pm 5.62$ & $60.51 \pm 18.54$ \\
\hline $\begin{array}{l}\text { Diatoms total } \\
\text { Skeletonema costatum } \\
\text { Rhizosolenia fragilissima }\end{array}$ & $\begin{array}{r}59.33 \pm 3.29 \\
3.75 \pm 1.99 \\
53.52 \pm 4.79\end{array}$ & $5.89 \pm 1.36$ & $3.40 \pm 1.60$ & $\begin{array}{l}88.39 \pm 2.97 \\
33.09 \pm 3.33 \\
46.01 \pm 4.42\end{array}$ & $7.84 \pm 4.28$ & $3.98 \pm 1.07$ \\
\hline $\begin{array}{l}\text { Dinophyceae total } \\
\text { Peridinium sp. } \\
\text { Prorocentrum micans }\end{array}$ & $15.13 \pm 3.48$ & $\begin{array}{r}63.40 \pm 7.63 \\
54.13 \pm 2.25 \\
2.90 \pm 0.20\end{array}$ & $\begin{array}{c}52.33 \pm 11.22 \\
50.14 \pm 10.70 \\
1.64 \pm 1.06\end{array}$ & & & $\begin{aligned} 28.92 & \pm 18.68 \\
0.75 & \pm 0.61\end{aligned}$ \\
\hline Naked flagellates & $4.44 \pm 1.34$ & $21.38 \pm 7.28$ & $31.35 \pm 7.52$ & $5.18 \pm 3.19$ & $73.00 \pm 10.46$ & $6.47 \pm 0.50$ \\
\hline Ciliates & $18.91 \pm 4.38$ & 0 & 0 & $1.68 \pm 0.73$ & 0 & 0 \\
\hline Amoeba & 0 & $0.10 \pm 0.09$ & $0.66 \pm 0.43$ & 0 & 0 & 0 \\
\hline \multicolumn{7}{|l|}{ Doliolids } \\
\hline Pico/nanoplankton $<5 \mu \mathrm{m}$ & $2.79 \pm 0.65$ & $9.43 \pm 1.86$ & $3.63 \pm 0.38$ & $1.61 \pm 0.54$ & $5.57 \pm 1.52$ & $5.02 \pm 1.06$ \\
\hline $\begin{array}{l}\text { Diatoms total } \\
\text { Skeletonema costatum } \\
\text { Rhizosolenia fragilissima }\end{array}$ & $\begin{array}{l}90.77 \pm 1.70 \\
11.03 \pm 5.40 \\
35.59 \pm 2.67\end{array}$ & $18.22 \pm 1.51$ & $\begin{aligned} 26.97 & \pm 11.86 \\
18.45 & \pm 10.49 \\
7.04 & \pm 1.06\end{aligned}$ & $\begin{array}{l}86.59 \pm 0.79 \\
56.90 \pm 11.26 \\
27.80 \pm 12.34\end{array}$ & $13.49 \pm 3.22$ & $12.89 \pm 2.07$ \\
\hline $\begin{array}{l}\text { Dinophyceae total } \\
\text { Peridinium sp. } \\
\text { Prorocentrum micans }\end{array}$ & $3.93 \pm 1.39$ & $\begin{array}{r}54.66 \pm 3.26 \\
47.19 \pm 4.57 \\
7.60 \pm 3.92\end{array}$ & $\begin{array}{r}43.63 \pm 0.24 \\
38.31 \pm 1.95 \\
6.84 \pm 2.48\end{array}$ & $7.50 \pm 2.37$ & $\begin{array}{r}64.20 \pm 7.99 \\
61.08 \pm 8.78 \\
2.72 \pm 0.91\end{array}$ & $\begin{array}{r}66.20 \pm 6.79 \\
59.86 \pm 9.35 \\
6.34 \pm 2.68\end{array}$ \\
\hline Naked flagellates & $0.48 \pm 0.16$ & $16.84 \pm 3.60$ & $25.73 \pm 12.49$ & $0.33 \pm 0.15$ & $0.58 \pm 0.38$ & $14.42 \pm 4.53$ \\
\hline Ciliates & $2.03 \pm 1.66$ & 0 & 0 & $3.97 \pm 3.24$ & 0 & 0 \\
\hline Amoeba & 0 & $0.85 \pm 0.70$ & $0.03 \pm 0.02$ & 0 & $16.17 \pm 7.31$ & $1.49 \pm 0.86$ \\
\hline \multicolumn{7}{|l|}{ Cladocerans } \\
\hline Pico/nanoplankton $<5 \mu \mathrm{m}$ & $2.26 \pm 0.36$ & $6.26 \pm 2.12$ & $4.78 \pm 0.39$ & $0.98 \pm 0.20$ & $4.66 \pm 0.09$ & $14.83 \pm 2.33$ \\
\hline $\begin{array}{l}\text { Diatoms total } \\
\text { Skeletonema costatum } \\
\text { Rhizosolenia fragilissima }\end{array}$ & $\begin{array}{r}60.58 \pm 3.52 \\
6.20 \pm 2.13 \\
51.60 \pm 1.23\end{array}$ & $26.69 \pm 10.76$ & $\begin{array}{r}41.15 \pm 5.26 \\
8.73 \pm 6.67 \\
18.68 \pm 8.86\end{array}$ & $\begin{array}{l}66.52 \pm 6.07 \\
56.90 \pm 11.26 \\
27.80 \pm 12.34\end{array}$ & $15.66 \pm 7.78$ & $\begin{array}{r}54.56 \pm 5.05 \\
8.78 \pm 3.15 \\
34.27 \pm 2.73\end{array}$ \\
\hline \multicolumn{7}{|l|}{ Dinophyceae } \\
\hline $\begin{array}{l}\text { Total } \\
\text { Peridinium sp. } \\
\text { Prorocentrum micans }\end{array}$ & $19.23 \pm 6.26$ & $\begin{aligned} 65.00 & \pm 12.31 \\
63.24 & \pm 11.85 \\
1.83 & \pm 0.47\end{aligned}$ & $28.11 \pm 7.28$ & $6.44 \pm 1.61$ & $\begin{aligned} 54.65 & \pm 21.56 \\
54.23 & \pm 21.55 \\
0.33 & \pm 0.05\end{aligned}$ & $11.56 \pm 7.93$ \\
\hline Naked flagellates & $1.73 \pm 0.40$ & $1.83 \pm 0.71$ & $22.89 \pm 4.01$ & $0.63 \pm 0.25$ & $0.18 \pm 0.10$ & $16.78 \pm 10.03$ \\
\hline Ciliates & $16.21 \pm 4.65$ & 0 & 0 & $25.43 \pm 6.32$ & $22.13 \pm 12.78$ & 0 \\
\hline Amoeba & 0 & $0.33 \pm 0.08$ & $3.07 \pm 2.44$ & 0 & $2.74 \pm 1.01$ & $2.27 \pm 1.00$ \\
\hline \multicolumn{7}{|l|}{ Controls } \\
\hline Pico/nanoplankton $<5 \mu \mathrm{m}$ & $2.57 \pm 0.08$ & $16.48 \pm 2.30$ & $6.16 \pm 0.40$ & $1.25 \pm 0.21$ & $20.61 \pm 7.12$ & $15.80 \pm 0.77$ \\
\hline $\begin{array}{l}\text { Diatoms total } \\
\text { Skeletonema costatum } \\
\text { Rhizosolenia fragilissima }\end{array}$ & $\begin{array}{l}64.89 \pm 5.45 \\
16.90 \pm 10.93 \\
42.49 \pm 16.00\end{array}$ & $19.22 \pm 2.70$ & $22.33 \pm 4.84$ & $\begin{array}{l}67.58 \pm 10.54 \\
30.23 \pm 10.09 \\
35.07 \pm 1.50\end{array}$ & $\begin{array}{l}44.10 \pm 3.29 \\
14.88 \pm 7.12 \\
27.18 \pm 6.86\end{array}$ & $\begin{array}{r}58.16 \pm 3.35 \\
0.31 \pm 0.02 \\
55.63 \pm 3.66\end{array}$ \\
\hline $\begin{array}{l}\text { Dinophyceae total } \\
\text { Peridinium sp. } \\
\text { Prorocentrum micans }\end{array}$ & $17.25 \pm 1.45$ & $\begin{array}{l}43.47 \pm 5.36 \\
30.89 \pm 4.64 \\
12.77 \pm 1.45\end{array}$ & $\begin{array}{l}43.99 \pm 5.32 \\
26.83 \pm 2.81 \\
13.38 \pm 0.24\end{array}$ & $3.90 \pm 1.07$ & $\begin{array}{r}31.59 \pm 6.93 \\
21.36 \pm 8.30 \\
9.77 \pm 0.73\end{array}$ & $21.97 \pm 1.34$ \\
\hline Naked flagellates & $4.60 \pm 1.43$ & $18.34 \pm 7.61$ & $27.53 \pm 0.08$ & $0.90 \pm 0.22$ & $1.62 \pm 1.24$ & $4.08 \pm 1.24$ \\
\hline Ciliates & $10.69 \pm 4.44$ & $0.30 \pm 0.24$ & 0 & $26.36 \pm 9.12$ & 0 & 0 \\
\hline Amoeba & 0 & $2.19 \pm 1.13$ & 0 & 0 & $2.07 \pm 1.26$ & 0 \\
\hline
\end{tabular}


Table 4. Similarity between plankton communities at the end of the experiment expressed as average distances, $d_{j k}$ (see 'Materials and methods': Eq. 2)

\begin{tabular}{|lcccc|}
\hline 1st stage & Copepods & Doliolids & Cladocerans & Controls \\
\hline Copepods & - & 11.09 & 18.91 & 8.95 \\
Doliolids & & - & 8.76 & 2.28 \\
Cladocerans & & & - & 10.32 \\
Controls & & & & - \\
\hline
\end{tabular}

$\left.\mathrm{ml}^{-1}\right)$ and highest bacterial biovolumes $\left(2.50 \times 10^{5} \mu^{3}\right.$ $\mathrm{ml}^{-1}$ ). In contrast, treatments with copepods showed

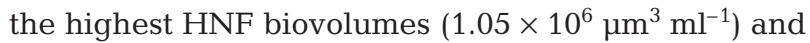

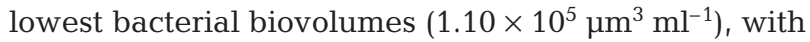
even fewer bacteria than the controls $\left(1.26 \times 10^{5} \mu^{3}\right.$ $\mathrm{ml}^{-1}$ ). Under the influence of doliolids HNF had lower

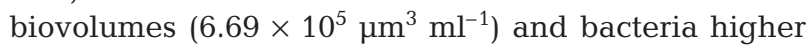

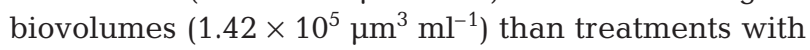
copepods and controls.

The ratio of autotrophic to heterotrophic flagellates (5.1 to $10 \mu \mathrm{m}$ size) increased during the experimental term compared to the initial seawater $(21 \%$ autotrophs). The increase was significant for all treatments (1-way ANOVA, $\left.\mathrm{p} \leq 0.05, F_{4,14}=6.866\right)$. Chemostats with doliolids had the highest proportion of autotrophs (63 $\pm 4 \%$ SE of the means, cladocerans: $43 \pm 12 \%$, copepods: $31 \pm 4 \%$, controls: $27 \pm 5 \%$ ). Post hoc Tukeytest analyses showed that systems with doliolids formed a separate group (Fig. 5).

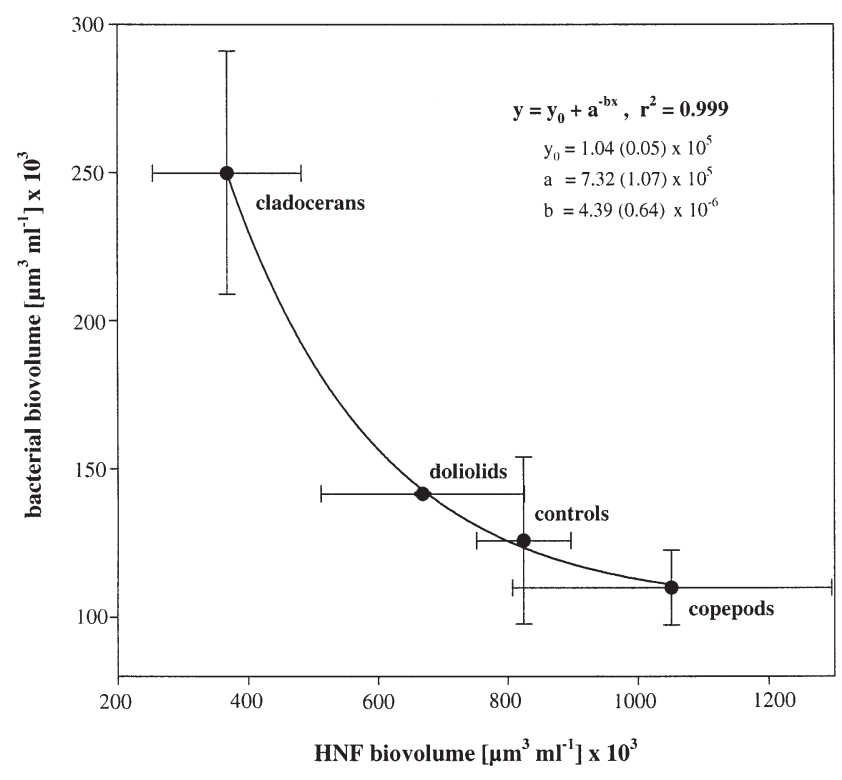

Fig. 4. Nonlinear regression analysis of heterotrophic nanoflagellate (HNF) biovolume (5.1 to $10 \mu \mathrm{m}$ size) on bacterial biovolume (bacteria + coccal cyanobacteria). Values in parentheses are $\mathrm{SE}, \mathrm{p}<0.05$. Data points are means of triplicates; error bars represent $\pm \mathrm{SE}$ of the means

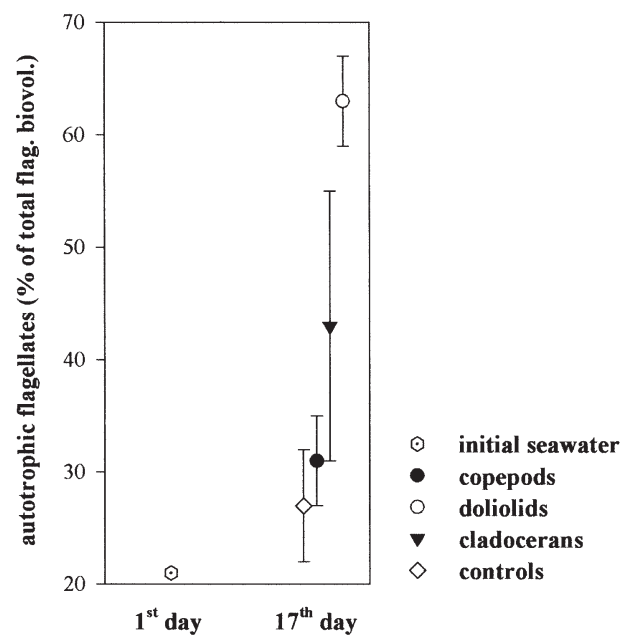

Fig. 5. Changes in the density of autotrophic flagellates as percentage total flagellate biovolume (5.1 to $10 \mu \mathrm{m}$ size). Data points are means of triplicates; error bars represent \pm SE of the means

\section{Changes in nutrient regime}

\section{$\mathrm{C}: \mathrm{N}$ ratios}

The C:N ratios of copepods, cladocerans and doliolids did not differ significantly from each other (1-way ANOVA, $\left.p=0.576, F_{2,7}=0.168\right)$. At the end of the experiment, the particulate $\mathrm{C}: \mathrm{N}$ ratios in 1 st stage flasks approached the Redfield ratio (106:16, Redfield 1958; cf. Copin-Montegut \& Copin-Montegut 1983) best in controls $(117: 16)$ and deviated most from it in treatments with cladocerans (141:16). Differences were not significant (1-way ANOVA, $\mathrm{p}=0.681, F_{4,13}=$ 0.586). For results see Table 5.

\section{Dissolved nutrients}

At the end of the experiment silicate, nitrate, ammonium and phosphate concentrations were higher in chemostats influenced by grazers than in controls (Fig. 6). In 1st stage flasks differences were only significant for silicate (1-way ANOVA p $\leq 0.05, F_{3,9}=15.176$ ) between copepod and doliolid treatments, between doliolid treatments and controls, and between controls and cladoceran treatments (post hoc Tukey-test p < 0.05). In 2 nd stage flasks differences were only significant for ammonium (1-way ANOVA, $p \leq 0.001, F_{3,9}=$ 45.636). Copepod treatments showed higher values than all other treatments and the ammonium concentrations in the cladoceran treatments were higher than in controls. These differences were significant (post hoc Tukey-test, p < 0.05). 
Table 5. C:N ratio of grazers and of the summer plankton community in Blanes Bay (NW Mediterranean) before (initial seawater) and after prolonged grazing pressure by doliolids, cladocerans or copepods. Values in parentheses are SE of the means

\begin{tabular}{|lc|}
\hline Sample & C:N (SE) \\
\hline Food guild & \\
Initial seawater & $9.27(0.36)$ \\
Copepod-chemostats & $8.64(0.40)$ \\
Doliolid-chemostats & $8.72(1.51)$ \\
Cladoceran-chemostats & $8.79(0.17)$ \\
Controls & $7.32(1.10)$ \\
Grazer & \\
Copepods & $4.57(0.25)$ \\
Doliolids & $4.50(0.05)$ \\
Cladocerans & $4.84(0.23)$ \\
Redfield ratio & 6.63 \\
\hline
\end{tabular}

At the end of the experiment, Si:N stoichiometry was more or less in accordance with the Redfield ratio (1:1 in all 1st stage flasks and in 2nd stage control flasks), but lower in chambers with grazers (Fig. 7). The N:P ratio was much lower than the Redfield ratio (16:1) in all 1st stage flasks. In 2nd stage flasks grazer exudates effected higher N:P values. Systems influenced by copepods corresponded best with the Redfield ratio. Chemostats with doliolids or cladocerans caused lower $\mathrm{N}$ :P ratios, although they were higher than those found in controls.

\section{DISCUSSION}

We used semicontinuous, re-circulating, 2-stage chemostats to study how doliolids, cladocerans and copepods can influence the phytoplankton community structure in Blanes Bay (Catalan Sea, NW Mediterranean). Semi-continuous chemostats permit a good approximation to the results gained from continuous designs (Sommer 1985), and have been proved to be effective tools in testing for direct and indirect effects of herbivore grazing on algae (e.g. Sommer 1988, 1998b).

\section{Changes in composition of food guilds}

Phytoplankton between 15 and $70 \mu \mathrm{m}$ dominated both stages of all chemostats influenced by herbivores. This is surprising, because food size spectra of all grazer types span this size class (Katechakis 1999). Possible reasons could be unpalatability of organisms, toxicity, higher competitive abilities than other phyto- plankton, or allelopathic effects. We will discuss these alternatives below.

Experiments were conducted in late August when copepods, cladocerans and doliolids are present in high abundances in Blanes Bay (500 to 780, 750 to 1250 and 90 ind. $\mathrm{m}^{-3}$, respectively: Andreu \& Duarte 1996), and the clear-water stadium has almost been reached (Mura et al. 1996, Satta et al. 1996). Hence, the natural (initial) community may already have been adapted to high grazing pressure. On the other hand, mostly Bacillariophyceae, mainly Skeletonema costatum and Rhizosolenia fragilissima, comprised the size class between 15 and $70 \mu \mathrm{m}$ until Day 6 (Table 2) and both species are considered food suitable for copepods (e.g. Paffenhöfer \& Knowles 1978, Ryther \& Sanders 1980), cladocerans and doliolids (Katechakis 1999).

By Day 12, Dinophyceae dominated the same size class, principally Peridinium sp. and Prorocentrum micans. Both taxa are classified as potentially toxic. This possibly affected grazers adversely and benefited dinoflagellates compared to other plankton. Toxicity can be a potent instrument against grazers, particularly against selective feeders such as copepods (Granéli 1990). As we did not test for toxicity we do not know if species were really toxic. However, we did not observe any obvious detrimental effect on the grazers.

Another explanation for the observed dominance of dinoflagellates could have been allelopathic effects on other phytoplankton species. To test for allelopathy was not a topic of this work. Also, we could find no reports about possibly allelopathic effects of Peridinium or Prorocentrum species in the literature.

Organisms of intermediate size may also profit, by being (1) too large to be fed on by protozoans, but (2) small enough to be better competitors than larger algae for nutrients.

Only in 2nd stage flasks of the control treatments did large phytoplankton $(>210 \mu \mathrm{m})$ dominate at the end of the experiment (Fig. 2). These were exclusively diatoms of the genus Rhizosolenia and sporadically Nitzschia spp. colonies (Table 1). They may have developed because of the high Si:N ratios in 2nd stage flasks in the control treatments (Fig. 7). A similar rise in large (and, due to their size, inedible) algae was observed during mesocosm experiments with high nutrient supplies in Blanes Bay (Y. Olsen unpubl. data). Differences between the 1st stage and 2nd stage control flasks may have resulted from higher Si concentrations in the 2nd stage flasks (Fig. 6). In addition it is conceivable that Bacillariophyceae benefited from dark incubation in the 2nd stage flasks, which contained high cell quotas of nitrogen and phosphorus. However, measurements cell quotas for different marine phytoplankton (Y. Olsen unpubl. data) provide no evidence for this assumption. 

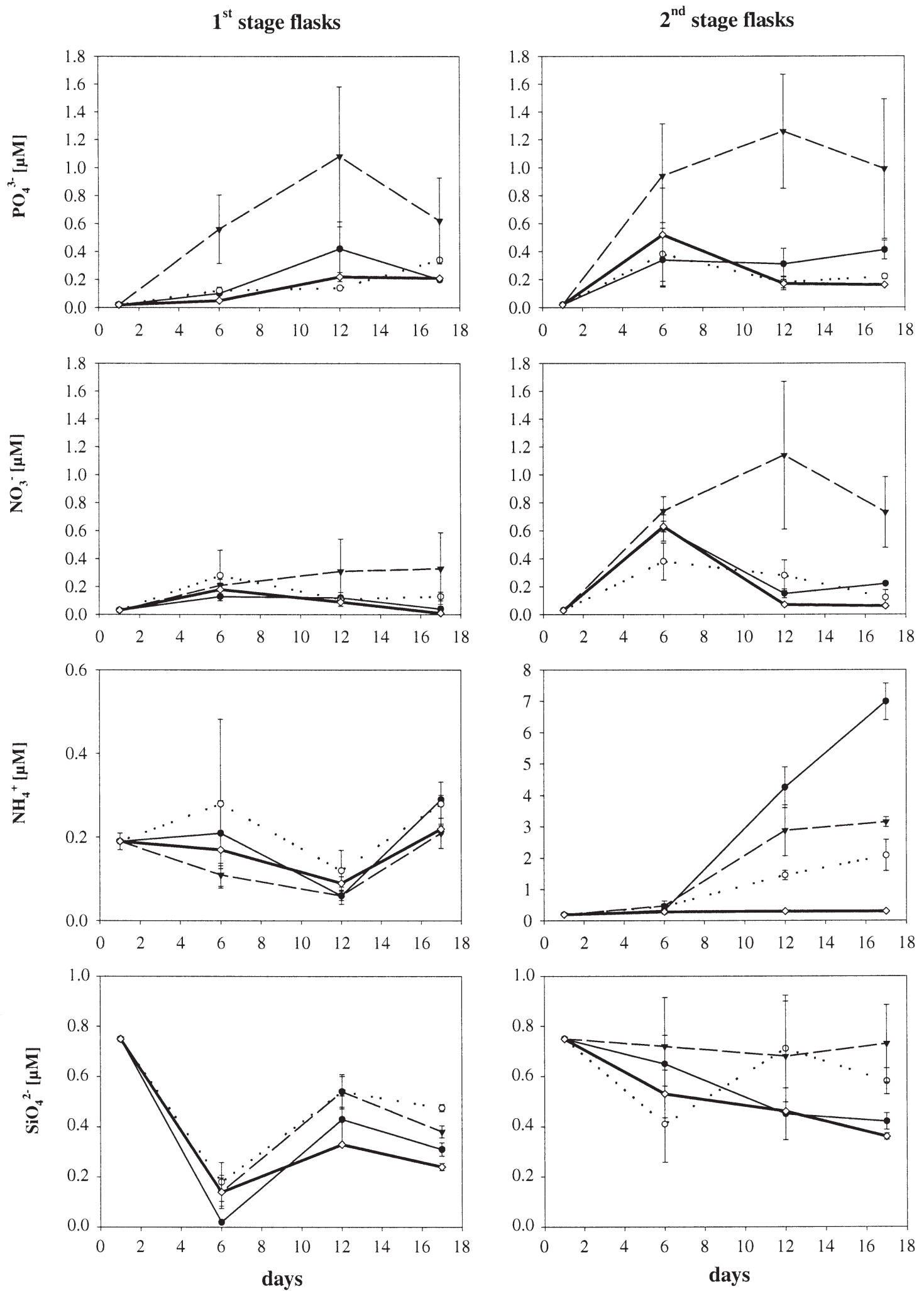

Fig. 6. Changes in the dissolved nutrient concentrations in 1st stage (left) and 2nd stage (right) flasks during the course of the experiment. Data points are means of triplicates; error bars represent \pm SE of the means 
$1^{\text {st }}$ stage flasks
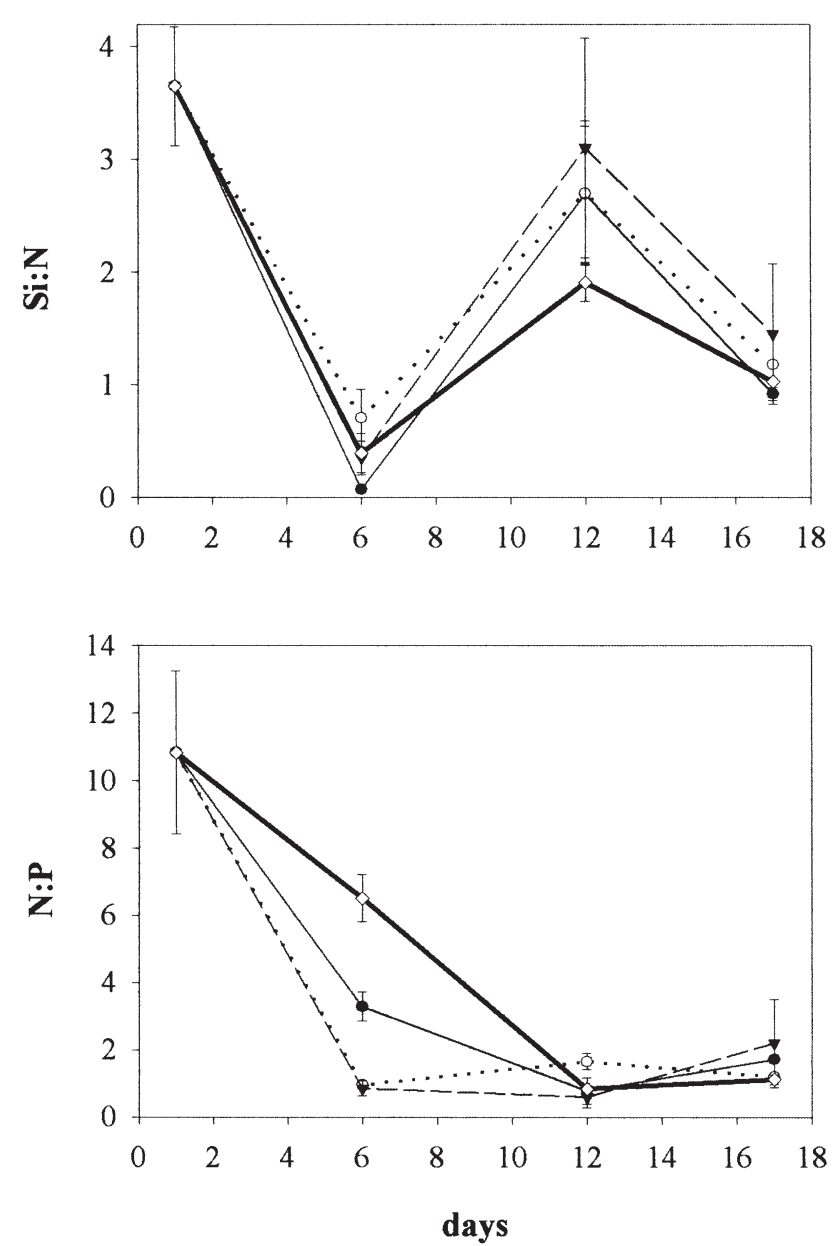

$2^{\text {nd }}$ stage flasks
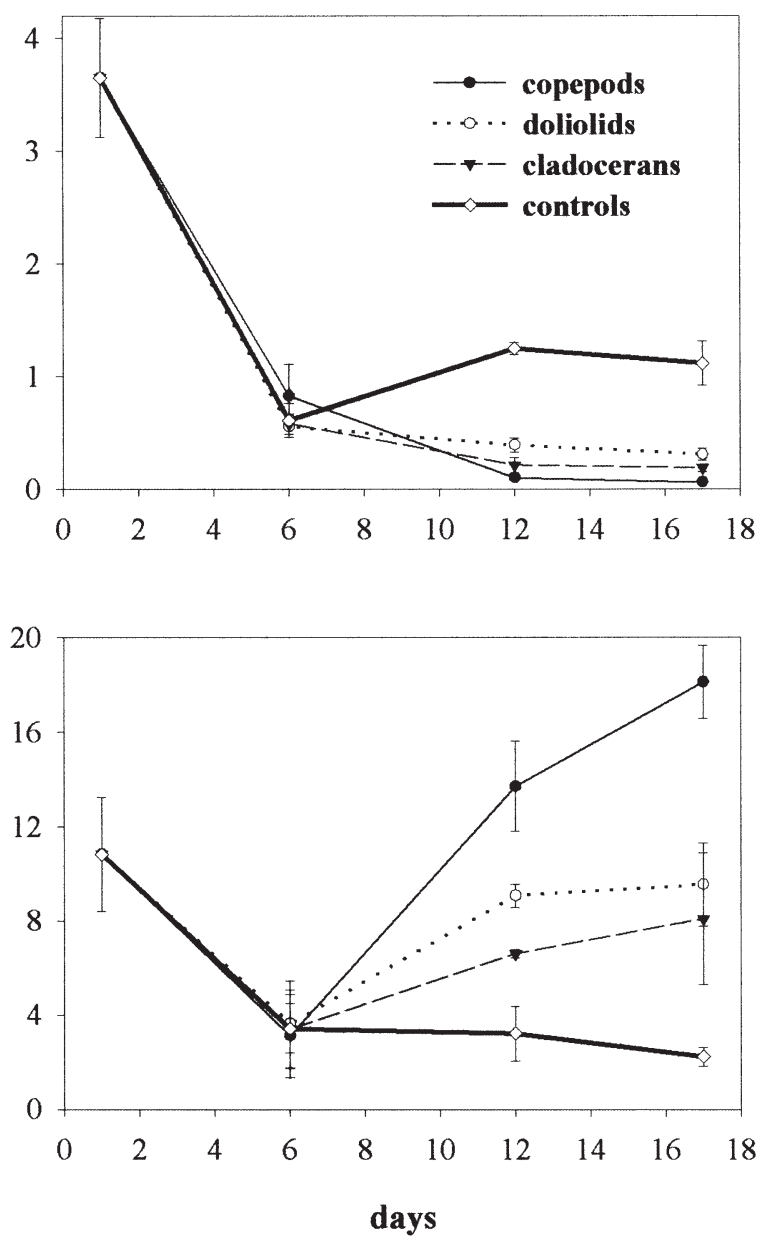

Fig. 7. Changes in the Si:N and N:P stoichometry in 1st stage (left) and 2nd stage (right) flasks during the course of the experiment. Data points are means of triplicates; error bars represent $\pm \mathrm{SE}$ of the means

Various studies have suggested that competition between diatoms and flagellates is determined by the stoichiometry of dissolved nutrients. If $\mathrm{Si}$ is not limiting, diatoms usually dominate over non-siliceous species (e.g. Officer \& Ryther 1980, Tilman et al. 1986, Cadée \& Hegeman 1991, Sommer 1994a,b,c, 1998a,b). In the present study, grazers have influenced the nutrient regime in reaction chambers through their excretions; by increasing the dissolved nutrient concentrations, they changed the stoichiometry in relation to controls. This effect was weaker in 1st stage than in 2nd stage flasks. The stoichiometry of 1st stage flasks deviated little from that in controls at the end of the experiment (Fig. 7). It seems that the food organisms immediately assimilated the added dissolved nutrients indicating that their growth was nutrient-limited. The $\mathrm{C}: \mathrm{N}$ data (Table 5) support this assumption. Biomass stoichiometry is an indicator of nutrient status (Droop 1974, 1975, Healey 1978, Healey \& Hendzel 1980). All the plankton communities exposed to grazers had $\mathrm{C}: \mathrm{N}$ ratios $>8.3$, indicating moderate N-limitation according to Healey \& Hendzel (1980) and Hecky et al. (1993).

In size classes smaller and larger than 15 to $70 \mu \mathrm{m}$, grazers supported particle sizes outside their specific grazing spectra (Fig. 2). Unexpected distributions compared with controls occurred in chemostats influenced by doliolids, where large food-item levels $(>100 \mu \mathrm{m})$ decreased, and in treatments with copepods, where picoplankton levels decreased. Doliolids efficiently decimated organisms $>100 \mu \mathrm{m}$, although the maximum food size ingestible for Doliolum denticulatum was $75 \mu \mathrm{m}$ in grazing experiments with natural plankton communities of Blanes Bay (Katechakis 1999). This can be explained by the circumstance that in this size class only long-chain diatoms (Rhizosolenia spp. and Skeletonema costatum) occurred, whose ingestibility depends on their orientation in the filtration stream. 
Since their valve diameters are between 10 and $20 \mu \mathrm{m}$, it is possible that they were ingested.

The same grazing experiments showed that copepods were not able to pick up particles $<7.5 \mu \mathrm{m}$. Yet temporarily, the proportion of picoplankton was lowest under the influence of copepods. This may be due to trophic cascade effects and will be discussed in the following section together with the implications for the microbial food web.

Measurements of similarity suggest that the potential to modify a given algal population increases with increasing selectivity of the grazer (Table 4).

\section{Changes in composition of microbial food web (1st stage flasks)}

The abundances of solitary bacteria determined in the initial samples correspond well with results of Vaqué (1996) for Blanes Bay. During the course of the experiment HNF abundances influenced the abundance of solitary bacteria. High HNF densities were accompanied by low densities of solitary bacteria, including coccal cyanobacteria (Fig. 4). The inability of copepods to ingest particles $<7.5 \mu \mathrm{m}$ led to higher HNF densities than in other treatments. This explains the low bacterial abundances in chemostats with copepods. Conversely, Penilia avirostris exerted the largest grazing pressure on HNF of all grazers, although this species cannot graze on the bacteria themselves (Turner at al. 1988, Katechakis 1999). Accordingly, the cladoceran treatment resulted in the highest bacteria numbers. Doliolids caused medium HNF and bacteria densities. Jürgens et al. (1994), Jürgens (1995), Jürgens \& Jeppesen (2000) described similar cascading effects for limnic systems. In lakes, strong top-down effects in the pelagic are well known (Carpenter at al. 1985). It is still not clear whether such trophic cascades occur in the marine pelagic. The interactions in our experiments between mesozooplankton and the microbial food web suggest that a top-down transmission of effects can occur, at least in the lower trophic levels. Recent enclosure experiments with carnivorous mesozooplankton and natural algal communities in the NE Atlantic indicate that such effects can also occur at higher trophic levels (H.S. et al. unpubl. data).

The differences in the appearance of particle-bound bacteria and filamentous cyanobacteria between the treatments arise from an adaptation to the different kind of grazing pressures exerted by copepods, cladocerans or doliolids. Abundances of both bacterial groups increased most under the influence of doliolids (Fig. 3). Filamentous cyanobacteria of all sizes (7 to $140 \mu \mathrm{m}$ ) lay inside the food size spectrum of cladocerans and copepods, but not inside the food size spec- trum of doliolids, as evaluated in grazing experiments with natural phytoplankton assemblages from Blanes Bay (Katechakis 1999). Indeed 18.9\% ( $\pm 5.8 \% \mathrm{SE}$ of the mean) of the total filamentous cyanobacterial biovolume lay over the maximum size doliolids can manipulate. As well, we found many more particles in treatments with doliolids than in other chemostats. The combination of a higher density of particles in chambers with doliolids and the production of particles larger than the ingestible food size for doliolids may explain the differences in particle-bound bacteria numbers between the doliolid treatments and the other chemostats. An elongated shape and attachment to particles can be an effective bacterial defence against grazing. Various authors have documented this for freshwater systems with respect to bacterivorous protists (e.g. Güde 1989, Šimek \& Chrzanowski 1992, Jürgens et al. 1994, Jürgens 1995, Jürgens \& Jeppesen 2000) and metazoan predation (Langenheder \& Jürgens 2001). Little is known about similar processes in marine environments. In particular, the importance of bacterivorous metazooplankton such as appendicularians and doliolids may be underestimated.

The general increase of cyanobacteria in all 1st stage chemostats (Fig. 3) may be explained by the fact that the high light intensity was advantageous to cyanobacteria (Sommer 1994c).

The ratio of autotrophic to heterotrophic flagellates was highest in chemostats with doliolids, and these were the only treatments that differed significantly from controls (Fig. 3). The annual average autotrophic nanoflagellates (ANF) is $50.2 \%$ of the nanoflagellate community in Blanes Bay (Vaqué 1996). Under the influence of doliolids, the proportion was $13 \%$ higher. One conceivable cause is that doliolids competed with HNF for bacteria, so that the relative proportion of ANF increased. Comparable changes in situ might have consequences for the trophic interactions at lower trophic levels, as the grazing pressure on the microbial food web would be altered. Carbon demands should rise relative to production and, hence, lead to the potential for top-down control of bacterial biomass and production. Changes in food chain length and energetic transfer efficiency might follow.

Our results show that in marine systems direct and indirect effects of herbivores can result in trophic cascades and that the effects of herbivores on phyto-, protozoo- and bacterioplankton strongly depend on the taxonomic compostion of the herbivores. This has implications for the modeling of grazing effects in marine pelagic ecosystems.

Acknowledgements. This article is a contribution to the MAST III-project COMWEB founded by the EU (MAST3CT96-0052). 


\section{LITERATURE CITED}

Alldredge AL, Madin LP (1982) Pelagic tunicates: unique herbivores in the marine plankton. BioScience 32(8):655-663

Andersen $\mathrm{T}$ (1997) Pelagic nutrient cycles: herbivores as sources and sinks. Ecol Stud 129:1-280

Andreu P, Duarte CM (1996) Zooplankton seasonality in Blanes Bay (northwest Mediterranean). Publ Espec Inst Esp Oceanogr 22:47-54

Bjørnsen PK (1986) Automatic determination of bacterioplankton biomass by image analysis. Appl Environ Microbiol 51(6):1199-1204

Booth BC, Lewin J, Norris RE (1982) Nanoplankton species predominant in the subarctic Pacific in May and June 1978. Deep-Sea Res Part I 29(2):185-200

Bøsheim KY, Bratbak G (1987) Cell volume to carbon conversion factors for a bacterivorous Monas sp. enriched from seawater. Mar Ecol Prog Ser 8:211-223

Cadée GC, Hegeman J (1991) Historical phytoplankton data for the Marsdiep. Hydrobiol Bull 29:111-119

Carpenter SR, Kitchell JF, Hodgson DR (1985) Cascading trophic interactions and lake productivity. BioScience 35: 634-639

Copin-Montegut C, Copin-Montegut G (1983) Stoichiometry of carbon, nitrogen, and phosphorus in marine particular matter. Deep-Sea Res 30:31-46

Crocker KM, Alldredge AL, Steinberg DK (1991) Feeding rates of the doliolid, Dolioletta gegenbauri, on diatoms and bacteria. J Plankton Res 13(1):77-82

Cushing DH (1975) Marine ecology and fisheries. Cambridge University Press, Cambridge

DeBiase AER, Sanders RW, Porter KG (1990) Relative nutritional value of ciliate protozoa and algae as food for Daphnia. Microb Ecol 19:99-210

Deibel D (1982a) Laboratory determined mortality, fecundity, and growth rates of Thalia democratica Forskal and Dolioletta gegenbauri Uljanin (Tunicata, Thaliacea). J Plankton Res 4:143-153

Deibel D (1982b) Laboratory-measured grazing and ingestion rates of the salp, Thalia democratica Forskal, and the doliolid, Dolioletta gegenbauri Uljanin (Tunicata, Thaliacea). J Plankton Res 4(2):189-202

Deibel D (1998) The abundance, distribution and ecological impact of doliolids. In: Bone Q (ed) The biology of pelagic tunicates. Oxford University Press, Oxford, p 171-186

Droop MR (1974) The nutrient status of algal cells in continuous culture. J Mar Biol Assoc UK 54:825-855

Droop MR (1975) The nutrient status of algal cells in batch culture. J Mar Biol Assoc UK 55:541-555

Escaravage V, Prins TC, Smaal AC, Peeters JHC (1996) The response of phytoplankton communities to phosphorous input reductions in mesocosm experiments. J Exp Mar Biol Ecol 198:55-79

Fuhrmann JA, Azam F (1980) Bacterioplankton secondary production estimates for coastal waters off British Columbia, Antarctica and California. Appl Environ Microbiol 39: 1085-1095

Gismervik I, Andersen T, Vadstein O (1996) Pelagic food webs and eutrophication of coastal waters: impact of grazers on algal communities. Mar Pollut Bull 33(1-6): 22-35

Granéli E (ed) (1990) Toxic marine phytoplankton. Elsevier, New York

Grasshoff K, Kremling K, Ehrhardt M (1983) Methods of seawater analysis. Wiley-VCH, Weinheim

Güde H (1989) The role of grazing on bacteria in plankton succession. In: Sommer U (ed) Plankton ecology, succes- sion in plankton communities. Springer-Verlag, Berlin, p 365-374

Healey FP (1978) Physiological indicators of nutrient deficiency in algae. Mitt Int Ver Theor Angew Limnol 21: $34-41$

Healey FP, Hendzel LL (1980) Physiological indicators of nutrient deficiency in lake phytoplankton. Can J Fish Aquat Sci 37:442-453

Hecky RE, Campbell P, Hendzel LL (1993) The stoichiometry of carbon, nitrogen, and phosphorus in particulate matter of lakes and oceans. Limnol Oceanogr 38:709-724

Hessen DO, Andersen T (1992) The algae-grazer interface: feedback mechanisms linked to elemental ratios and nutrient cycling. Ergeb Limnol 35:111-120

Hillebrand H, Dürselen CD, Kirschtel D, Pollingher U, Zohary $\mathrm{T}$ (1999) Biovolume calculation for pelagic and benthic microalgae. J Phycol 35(2):403-424

Iverson RL (1990) Control of marine fish production. Limnol Oceanogr 35:1593-1604

Jürgens K (1995) Die Bedeutung heterotropher Nanoflagellaten als Bakterienkonsumenten sowie deren Regulation durch Prädation und Ressourcen. Berichte aus der Biologie, Shaker, Aachen

Jürgens K, Jeppesen E (2000) The impact of metazooplankton on the structure of the microbial food web in a shallow, hypertrophic lake. J Plankton Res 22(6):1047-1070

Jürgens K, Arndt H, Rothhaupt KO (1994) Zooplankton-mediated change of bacterial community structure. Microb Ecol 27(1):27-42

Katechakis A (1999) Nischenüberlappung zwischen herbivorem gelatinösen- und Crustaceen-Zooplankton im NW-Mittelmeer (Catalanisches Meer). Thesis, Universität Kiel

Kiørboe T (1998) Population regulation and role of mesozooplankton in shaping marine pelagic food webs. Hydrobiologia 363:13-27

Langenheder S, Jürgens K (2001) Regulation of bacterial biomass and community structure by metazoan and protozoan predation. Limnol Oceanogr 46(1):121-134

Lund JWG, Kipling C, LeCren ED (1958) The inverted microscope method of estimating algal numbers and the statistical basis of estimations by counting. Hydrobiologia 11: $147-170$

Miralto A, Barone G, Romano G, Poulet AS and 7 others (1999) The insidious effect of diatoms on copepod reproduction. Nature 402:173-176

Mura MP, Agusti S, Cebrian J, Satta-MP (1996) Seasonal variability of phytoplankton biomass and community composition in Blanes Bay (1992-1994). Publ Espec Inst Esp Oceanogr 22:23-29

Officer CB, Ryther JH (1980) The possible importance of silicon in marine eutrophication. Mar Ecol Prog Ser 3:83-91

Paffenhöfer GA, Knowles SC (1978) Feeding of marine planktonic copepods on mixed phytoplankton. Mar Biol 48(2): 143-152

Paffenhöfer GA, Stewart TB, Youngblouth MJ, Bailey TG (1991) High resolution vertical profiles of pelagic tunicates. J Plankton Res 13:971-981

Porter KG, Feig YS (1980) The use of DAPI for identifying and counting aquatic microflora. Limnol Oceanogr 25:943-948

Redfield AC (1958) The biological control of the chemical factors in the environment. Am Sci 46:205-221

Reid FMH (1983) Biomass estimation of components of the marine nannoplankton and picoplankton by the Utermoehl settling technique. J Plankton Res 5(2):235-252

Ryther JH, Sanders JG (1980) Experimental evidence of zooplankton control of the species composition and size distri- 
bution of marine phytoplankton. Mar Ecol Prog Ser 3(4): $279-283$

Satta MP, Agusti S, Mura MP, Duarte CM (1996) Seasonal variability of planktonic gross primary production in Blanes Bay (March 1992-March 1994). Publ Espec Inst Esp Oceanogr 22:31-38

Schöllhorn E, Granéli E (1996) Influence of different nitrogen to silica ratios and artifical mixing on the structure of a summer phytoplankton community from the Swedish west coast (Gullmar Fjord). J Sea Res 35:159-167

Šimek K, Chrzanowski TH (1992) Direct and indirect evidence of size-selective grazing on pelagic bacteria by freshwater nanoflagellates. Appl Environ Microbiol 58: 3715-3720

Simon M, Azam F (1989) Protein content and protein synthesis rates of planktonic marine bacteria. Mar Ecol Prog Ser 51:201-213

Sommer U (1983) Nutrient competition between phytoplankton species in multispecies chemostat experiments. Arch Hydrobiol 96:399-416

Sommer U (1985) Comparison between steady state and non steady state competition: experiments with natural phytoplankton. Limnol Oceanogr 30(2):335-346

Sommer U (1988) Phytoplankton succession in microcosm experiments under simultaneous grazing pressure and resource limitation. Limnol Oceanogr 33:1037-1054

Sommer U (1994a) Are marine diatoms favored by high Si:N ratios? Mar Ecol Prog Ser 115:309-315

Sommer U (1994b) The impact of light intensity and daylength on silicate and nitrate competition among marine phytoplankton. Limnol Oceanogr 39(7):1680-1688

Sommer U (1994c) Planktologie. Springer-Verlag, Berlin, Heidelberg

Sommer U (1996) Nutrient competition experiments with

Editorial responsibility: Otto Kinne (Editor),

Oldendorf/Luhe, Germany periphyton from the Baltic Sea. Mar Ecol Prog Ser 140: 161-167

Sommer U (1998a) Silicate and the functional geometry of marine phytoplankton. J Plankton Res 20(9):1853-1859

Sommer U (1998b) From algal competition to animal production: enhanced ecological efficiency of Brachionus plicatilis with a mixed diet. Limnol Oceanogr 43(6):1393-1396

Sommer U, Stibor H, Katechakis A, Hansen T (2002) Pelagic food web configurations at different levels of nutrient richness and their implications for the ratio fish production:primary production. Hydrobiologia (in press)

Strickland J, Parsons TR (1972) A practical handbook of seawater analysis, 2nd edn. Bull Fish Res Board Can 167:1-310

Tang KW, Dam HG (2001) Phytoplankton inhibition of copepod egg hatching: test of an exudate hypothesis. Mar Ecol Prog Ser 209:197-202

Tilman D (1982) Resource competition and community structure. Princeton University Press, Princeton, NJ

Tilman D, Kiesling R, Sterner RW, Kilham SS, Johnson FA (1986) Green, blue-green and diatom algae: taxonomic differences in competitive ability for phosphorus, silicon and nitrogen. Arch Hydrobiol 106:473-485

Turner JT, Tester PA, Ferguson RL (1988) The marine cladoceran Penilia avirostris and the 'microbial loop' of pelagic food webs. Limnol Oceanogr 33(2):245-255

Utermöhl H (1958) Zur Vervollkommnung der quantitativen Phytoplankton-Methodik. Mitt Int Verein Theor Angew Limnol 9:1-38

Vaqué D (1996) Seasonal dynamics of planktonic microbial communities on the coast of the northwest Mediterranean Sea. Publ Espec Inst Esp Oceanogr 22:39-46

Verity PG, Smetacek V (1996) Organism life cycles, predation, and the structure of marine pelagic ecosystems. Mar Ecol Prog Ser 130:277-293

Submitted: April 25, 2001; Accepted: December 5, 2001

Proofs received from author(s): April 26, 2002 